\title{
SLASHER THERAPY: THE SLASHER MOVIE AS AN ALLEGORY FOR THE TRAUMA
}

TERAPIA SLASHER: O FILME SLASHER COMO

ALEGORIA DO TRAUMA

Amanda Leonardi de Oliveira' 
RESUMO: O objetivo deste estudo é a análise de dois filmes Slasher como possíveis alegorias para o processo terapêutico do trauma, propondo uma leitura do assassino Slasher como uma metáfora para a situação traumática. Para isso, os enredos dos filmes A Nightmare on Elm Street (Bayer, 2010) e Final Girls (Schulson, 2015) são lidos como possíveis alegorias para o processo psicanalítico em que as protagonistas lidam com seus traumas enquanto enfrentam os assassinos. Esta análise é realizada com base na estrutura do filme Slasher formada por Final girl contra o assassino Slasher, conforme definida por Carol Clover (1992). Além disso, como o confronto ocorre no lugar chamado por Clover de Terrible Place, a questão é comparada ao inconsciente e suas dinâmicas, como proposto por Sigmund Freud em The Ego and the Id (2019). A correlação de trauma e narrativas ficcionais apoia-se na obra de Cathy Caruth (1996) em que a conexão entre o trauma e a construção de narrativas é abordada.

PALAVRAS-CHAVE: Slashers; Trauma; Psicanálise; A Nightmare on Elm Street; Final Girls.

ABSTRACT: This study aims at analyzing two Slasher films as potential allegories for the therapeutic process of the trauma, proposing a reading of the Slasher killer as a metaphor for traumatic instances. For this analysis, the movie A Nightmare on Elm Street (Bayer, 2010) and Final Girls (Schulson, 2015) are read as possible allegories for a psychoanalytical process in which their Final Girls come to terms with their trauma as they face the killers. This analysis is performed based on the Slasher film structure as composed by the Final Girl versus the Slasher killer, as defined by Carol Clover (1992). Furthermore, as their confrontation takes place in what Clover calls the Terrible Place, so it is compared to the unconscious and its dynamics, counting on Sigmund Freud's The Ego and the Id (2019). The correlation of trauma and fictional narratives is carried out based on Cathy Caruth's studies of trauma (1996) and narrative construction.

KEYWORDS: Slashers; Trauma; Psychoanalysis; A Nightmare on Elm Street; Final Girls. 
According to American writer Stephen King, "we make up horrors to help us cope with the real ones" (2011, p. 11), and he could not have been more accurate in his description as to why we seek horror stories, either creating or consuming them. What matters is that we do seek them more often than not: even if it is not a genre that pleases everyone, as personal interests may vary, "many people—so many, in fact, that we must concede that they are normal, at least in the statistical sense-do seek out horror fictions for the purpose of deriving pleasure from sights and descriptions that customarily repulse them" (CARROLL, 1990, p. 158). So, we can say that humanity is in general naturally eager for what brings us chills, for that which makes hair stand on end, which is actually the definition for the word horror itself as it "derives from the Latin "horrere" - to stand on end (as hair does) or to bristle-and the old French "orror" - to bristle or to shudder" (CARROLL, 1990, p. 24). Now, why are we drawn towards horror stories? Or else, as proposed by the art philosopher Noel Carroll, "How can horror audiences find pleasure in what by nature is distressful and unpleasant?" (CARROLL, 1990, p. 159). Even though the focus of this study is not to answer this question in a broad sense, but rather to observe the relations between Slasher movies and the therapeutic process, it is first necessary to briefly demonstrate the connection between horror and the human psyche, as one of the reasons why we are often drawn to the horror genre.

Austrian psychoanalyst Sigmund Freud developed, in his book Beyond the Pleasure Principle, the theory of life drive versus death drive, the former representing actions that aim at survival and the prolongation of life, while the latter refers to destructive instincts, as they "arise from the coming to life of inanimate matter and seek to restore the inanimate state" (FREUD, 1961, p. 38). Each of those instincts are represented as Eros and Thanatos: Eros, the god of life, stands for the sexual instincts, whereas Thanatos symbolizes the deathly ones. "Eros and Thanatos work together and in the same direction, always seeking the individual's balance" (ZANINI, 2015, p. 100) ${ }^{2}$. Hence, the balance of these drives

2 Originally: "Eros e Tânatos trabalham juntos e na mesma direção, sempre na busca do equilíbrio do indivíduo." Tradução minha. 
is essential for a healthy psyche. Through consuming or producing horror stories, we are releasing what may be about to become unbalanced, satisfying the death drive through fictional devices. Also, working anxieties through fiction is a way to better deal with them as a "fantasy of anxiety prevents actual anxiety and its consequences" (STAIGER, 2015, p. 13). Still, according to Freud:

the artistic play and artistic imitation carried out by adults, which, unlike children's, are aimed at an audience, do not spare the spectators (for instance, in tragedy) the most painful experiences and can yet be felt by them as highly enjoyable. [...] there are ways and means enough of making what is in itself unpleasurable into a subject to be recollected and worked over in the mind (FREUD, 1961, p. 11).

This artistic play to which Freud refers shall concern, for this study, horror movies. Among the plenty existing horror movie genres, one which stands out is the Slasher. According to Carol Clover, this is the genre that lies "at the bottom of the horror heap" (1992, p. 21) in which we see an "immensely generative story of a psycho killer who slashes to death a string of mostly female victims, one by one, until he is subdued or killed, usually by the one girl who has survived" (CLOVER, 1992, p. 21). In her 1992 book Men Women and Chainsaw, Clover has defined the elements of the structure of a typical Slasher movie, and in this study I will focus on three of them which are the most central ones: the Slasher killer, the Final Girl and the Terrible Place.

The Slasher killer is usually a masked individual who is "the psychotic product of a sick family, but still recognizably human" (CLOVER, 1992, p. 23), and yet there is something that at first may seem awfully unhuman about them, once one may consider as unhuman and monstrous a body that is incomplete, skinless, or disfigured, burned, and/or hidden somehow. The masks or deformities that hide their humanity can be understood as representing their inner chaos transposed as their identities, as if their horrifying appearance were a symbol of their inner conflicts which never met a solution and reached a point to which it took over who they are. Most of Slasher killers have a traumatic past: Friday the 13th's Jason's 
mother lost her son due to the camp counselor's lack of attention; Jason himself drowned and then had his mother murdered; Freddy Kruger was burned alive; Billie Murphy, the Final Girls machete-wielding killer, was bullied and suffered third degree burns all over his body when he was attacked by bullies. This study shall focus mostly on the Final Girl's traumas and the way they face them while surviving the killer because, as I mean to demonstrate, that can be seen as a trauma recovery process. However, it is worth mentioning that the origin of most Slasher killers is also, most times, a traumatic event. The problem with the killer is that he is usually so possessed by his pain he cannot walk away from it, he can never recover from it, so he becomes its personification. He is, after all, a type of monster.

According to Jeffrey J. Cohen, the monster:

is born only at this metaphoric crossroads, as an embodiment of a certain cultural moment-of a time, a feeling, and a place. The monster's body quite literally incorporates fear, desire, anxiety, and fantasy (ataractic or incendiary), giving them life and an uncanny independence. The monstrous body is pure culture. A construct and a projection, the monster exists only to be read: the monstrum is etymologically "that which reveals", "that which warns, "a glyph that seeks a hierophant (COHEN, 1996, p. 4).

Therefore, in Slasher movies, these monsters can be read as the incorporation of all the fear and pain they were once submitted to, and then cannot do anything else but to attack others, spreading that pain and death, which is all they know. For Noel Carroll:

Within the context of the horror narrative, the monsters are identified as impure and unclean. They are putrid or moldering things, or they hail from oozing places, or they are made of dead or rotting flesh, or chemical waste, or are associated with vermin, disease, or crawling things. They are not only quite dangerous but they also make one's skin creep. Characters regard them not only with fear but with loathing, with a combination of terror and disgust (CARROLL, 1990, p. 23).

Cohen also affirms that "the monster is an incorporation of the Outside, the 
Beyond — of all those loci that are rhetorically placed as distant and distinct but originate Within"(1996, p. 7). That makes sense when we consider that the monster may seem yet more threatening in Slasher movies because their faces are usually hidden by masks or disfigured, as if they were

only slightly metamorphized from what they really cover. Just note how similar visually Jason's hockey mask is to that of a skeleton, to the finally corrupted body. The inside and the end are present on the surface. Part of the process of the chase and destruction is the increasing revelation via the body of the killer of the end of the process of what he is creating - death (STAIGER, 2015, p. 224).

Considering that the monster's appearance can be read as representing his destructive inner process, many times even rotting and repulsive, and that the monster, even though incorporating the beyond, actually originates from within, according to Cohen as aforementioned, we can understand the monster shows that which he carries inside, meaning the repressed. In order to make more sense of this analysis, it is relevant to understand what is meant by the word repressed in psychoanalysis. According to Freud,

[it]is the prototype of the unconscious for us. We see, however, that we have two kinds of unconscious - the one which is latent but capable of becoming conscious, and the one which is repressed and which is not, in itself and without more ado, capable of becoming conscious. This piece of insight into psychical dynamics cannot fail to affect terminology and description. The latent, which is unconscious only descriptively, not in the dynamic sense, we call preconscious; we restrict the term unconscious to the dynamically unconscious repressed; so that now we have three terms, conscious (Cs.), preconscious (Pcs.), and unconscious (Ucs.), whose sense is no longer purely descriptive (FREUD, 2019, p. 43).

Therefore, the unconscious repressed is the one which remains hidden. Freud also divides the psyche as composed by the Id, which he defines as 
the dark, inaccessible part of our personality [...] It is filled with energy reaching it from the instincts, but it has no organization, produces no collective will, but only a striving to bring about the satisfaction of the instinctual needs subject to the observance of the pleasure principle [...] (FREUD, 2019, p. 105-106).

Besides, there are also the Ego and the Superego: the former represents reason and prudence and exercises control over all mental processes, while the latter is formed by a set of cultural values and protects the Ego against the Id's impulses. In general, the Id is completely unconscious, while the Ego and Superego are both conscious and unconscious. However, there is a circumstance in which the unconscious, the repressed, is called upon the surface and it causes a disturbance, a phenomenon Freud defines as the uncanny - das unheimliche, which is when "everything that was meant to remain secret and hidden has come into the open" (SCHELLING apud FREUD, 2003, p. 132). So, we can understand the principle of the uncanny as the one which is at once familiar, and then it becomes strange, which is just like what happens when we are in the presence of the repressed, once it causes a disturbance of the balance of consciousness.

Therefore, the rising of the monster or the appearance of the killer in the horror movie may be considered an uncanny event, since it is perceived as beyond the normal or the expected. The arrival of a monstrous creature sets a move from familiar/normal to unfamiliar/abnormal - that is, what is familiar and dear to characters becomes unfamiliar and threatening. That happens mostly when we see the killer as representing something that was supposed to stay hidden but has then comes to the surface, which is especially true in the cases of Slasher movies in which "none of these killers has been properly buried. [...] They were thrust in a sack and hidden somewhere in a junkyard of old cars" (STAIGER, 2015, p. 224). They were not properly buried as the traumatic events they represent were not completely repressed and eventually come back to haunt us. As the Id coming out of the unconscious and generating chaos outside, the killer is representative of this violent instinct that is mostly repressed; yet, when released, it comes out as a threat to all those around, as it expresses an unbalanced system. Cohen also compares the 
ever returning nature of monsters to the uncanny return of the repressed, which, for this study, is exactly what the monster/the killer represents: "Like Grendel thundering from the mere or Dracula creeping from the grave, like Kristeva's "boomerang, a vortex of summons" or the uncanny Freudian-Lacanian return of the repressed, the monster is always coming back, always at the verge of irruption" (COHEN, 1996, p. 20).

Another key element of the Slasher movie is the Final Girl - the girl who survives at the end of the Slasher movie is what Clover calls the Final Girl. Unlike the other girls in the movie, she is usually a virgin and smarter than the other ones: "her smartness, gravity, competence in mechanical and other practical matters, and sexual reluctance set her apart from the other girls and ally her, ironically, with the very boys she fears or rejects, not to speak of the killer himself" (CLOVER, 1992, p. 40). Hence, being unlike the typical girly girls, she is "boyish, in a word" (CLOVER, 1992, p. 40). The Final Girl is the Slasher killer's main rival, the one who stands out and balances the battle of life against death.

She is the one who encounters the mutilated bodies of her friends and perceives the full extent of the preceding horror and of her own peril; who is chased, cornered, wounded; whom we see scream, stagger, fall, rise, and scream again. She is abject terror personified. [...] She alone looks death in the face, but she alone also finds the strength either to stay with the killer long enough to be rescued (ending A) or to kill him herself (ending B) (CLOVER, 1992, p. 35).

According to Vera Dika, "the opposition which separates the heroine from the killer is best described as ego/id" (DIKA, 1985, p. 96), and I partially agree with her: as observed earlier, the killer can be compared to the Id, yet the heroine, as the Final Girl, the girl who is the smartest, always keen and able to battle the killer, would be actually more comparable to the Superego, as she stands in opposition to the killer: her cleverness, her morality and her awareness are the aspects that demonstrate she can save herself, which she does in the end. Yet, she is different from the killer not only because she is the victim but also because, while the killer represents chaos, as the Id 
sets free in a destructive murderous spree, the Final Girl is usually very restricted when it comes to social life, being usually shy, somehow uptight and a virgin, which makes her most likely linked to the over watching Superego. So, she stands as a guardian between the destructive chaos brought by the killer and the balance of the world, as she represents order in contrast with the chaos introduced by the killer.

The third key element of the Slasher movie as defined by Clover is the Terrible Place, which is "most often a house or tunnel, in which victims sooner or later find themselves in a venerable element of horror" (CLOVER, 1992, p. 30). This element represents, in the Slasher movie, what in Gothic tradition is known as the locus horribilis, one of the main elements of Gothic narratives, which is defined as

oppressive narrative spaces which affect, when not also determine, the disposition and the actions of the characters who inhabit it. Environment may vary according to the cultural context of each narrative, yet either urban or rural and wild areas are described as horrifying places. Gothic narrative loci horribiles represent an essential element to produce fear as an aesthetic effect, once they express a sensation of discomfort and estrangement that the characters - and, by extension, the modern man - experience concerning the physical and social place they inhabit (FRANÇA, 2020, p. 117). ${ }^{3}$

For Clover, this place "may at first seem a safe haven, but the same walls that promise to keep the killer out quickly become, once the killer penetrates them, the walls that hold the victim in" (CLOVER, 1992, p. 30). Clover also describes the Terrible Place as "decidedly "intrauterine" in quality" (CLOVER, 1992, p. 48), as this place can often be

3 espaços narrativos opressivos, que afetam, quando não determinam, o caráter e as ações das personagens que lá vivem. Os ambientes podem variar conforme o contexto cultural de cada narração, mas tanto regiões selváticas, quanto áreas rurais e os grandes centros urbanos são descritos, de modo objetivo ou subjetivo, como locais aterrorizantes. Os loci horribiles da narrativa gótica são um elemento essencial para a produção do medo como efeito estético, já que expressam a sensação de desconforto e estranhamento que as personagens - e, por extensão, o homem moderno - experimentam ante o espaço físico e social em que habitam. Tradução minha. 
dark and often damp, in which the killer lives or lurks and whence he stages his most terrifying attacks. "It often happens", Freud wrote, "that neurotic men declare that they feel there is something uncanny about the female genital organs. This unheimlich place, however, is an entrance to the former Heim [home] of all human beings, to the place where each of us lived once upon a time and in the beginning. In this case too then, the unheimlich is what once was heimlich, familiar; the prefix 'un' [un-] is the token of repression (CLOVER, 1992, p. 48).

Clover also emphasizes how it is usually significant in Slasher movies "the moment that the killer leaps out of the dark recesses of a corridor or cavern at the trespassing victim, usually the Final Girl (CLOVER, 1992, p. 48), as well as how the "penetration scene is commonly the film's pivotal moment; if the victim has up to now simply fled, she now has no choice but to fight back" (CLOVER, 1992, p. 30). Taking into consideration Gaston Bachelard's view on the meanings of space in narratives, we must recall that "a house constitutes a body of images that give mankind proofs or illusions of stability. [...] A house is imagined as a vertical being [...] Verticality is ensured by the polarity of cellar and attic. It is possible to oppose the rationality of the roof to the irrationality of the cellar" (BACHELARD, 1994, p. 17-18). Therefore, whatever lies in the basement or cellar, in this hidden place underneath the surface, can represent the unconscious, that which has been repressed. Bachelard also affirms that the basement is "the dark entity of the house, the one that partakes subterranean forces. When we dream there, we are in harmony with the irrationality of the depths" (BACHELARD, 1994, p.17-18)

Hence, when we have scenes of the killer and the Final Girl in a battle in the Terrible Place, we can propose to read this type of scene as the Final Girl penetrating her unconscious, facing a trauma she has repressed, yet rises again, represented by the killer: the traumatic event, whichever it is, the past that always returns to hurt her again. Thus, the repetitive return of the killer can be compared to "the experience that Freud will call "traumatic neurosis" - [...] the unwitting reenactment of an event that one cannot simply leave behind" (CARUTH, 1996, p. 2). Now, considering the Final Girl as a representative of the Superego and the 
killer representing the Id, both battling in this Terrible Place, which represents the unconscious, we have a Freudian reading of the psyche represented by the elements of the Slasher movie as proposed by Clover. These elements must work together in order to keep a balanced psyche, except that when very traumatic situations take place, this balance is disrupted. Then it is also possible to interpret, in some movies, the whole action of Slasher Girl versus killer as a therapeutic process of uncovering traumatic events that were once repressed and facing them, not as if it were possible to completely overcome them, but coming to terms with them by reaching a breakthrough, which is what happens at the end of most Slasher movies: Final Girl faces the killer and survives - she survives what wounded her, and most of the times, also wounded others as well.

In the 2010 remake of $A$ Nightmare on Elm Street, directed by Samuel Bayer, we have teenagers being stalked in their dreams by a disfigured man with razor fingers. Some of them are murdered in their sleep, while others, the Final Girl, Nancy, being one of them, struggle to stay awake and avoid the attacks. Those who struggle manage to survive longer by understanding what is happening: by researching details of their dreams, they discover that the disfigured man who stalks them in their dreams was a man who had abused them in their preschool years. That was Freddy Krueger, who was burned to death by their parents as a revenge. The teenagers do not consciously remember the abuses, but the recurrence of Freddy attacking them in their dreams can be possibly read as repressed trauma, as hidden memories that keep coming back and reopening the wound of the traumatic events of the abuses again and again: a possible example of such is the scene in which Nancy finds herself, in a dream, wearing the same childhood dress that she used to wear at pre-school, and Freddy appears as a threat. In the dream, the threat is the violence imposed by his blade fingers and murderous attitude, but the symbology of Nancy wearing the same childhood dress and feeling threatened by Freddy's presence is that of her repressed trauma of the abuses suffered in her childhood. As appointed by Cathy Caruth, "trauma is not locatable in the simple violent or original event in an individual's past, but rather in the way that its very unassimilated nature-the way it was precisely not 
known in the first instance- returns to haunt the survivor later on." (CARUTH, 1996, p. 4). Hence, the fact that they could not assimilate the events of Freddy's abuses consciously in their childhood because they were too young, so they could not understand this wound they had, is what created the trauma which, according to Caruth, can be defined as when something is "experienced too soon, too unexpectedly, to be fully known and is therefore not available to consciousness until it imposes itself again, repeatedly, in the nightmares and repetitive actions of the survivor". (CARUTH, 1996, p. 3-4).

The return of Freddy Krueger in their nightmares is this repetitive imposition of the traumatic events, which can only be faced when thoroughly understood that is, when brought to consciousness. In Freddy's case, we can compare this act of bringing something from unconsciousness to consciousness to the act of bringing Freddy out of the dream world and into the physical, real world, which is what the protagonist, Nancy, does at the end of the movie to defeat the monster, as she remarks, “It hurts, doesn't it? That's 'cause you're in my world now, bitch!”. Therefore, "Freddy can only be defeated when dragged into the real world - our world" (ZANINI, 2019 , p. 209) because he represents the repressed, and it is only possible to come to terms with repressed traumatic events by bringing them to light, to our world. That makes it possible to read this movie as the Final Girl, Nancy, going through a painful therapeutic process of facing her past and coming to terms with it.

Another movie that can be read as a Slasher therapeutic process is 2015 Todd Strauss-Schulson's Final Girls. This movie plays with Slasher conventions as it places a story within a story, making characters struggle for survival as they know beforehand how the story unfolds and how the Slasher conventions affect its development: it starts with young Max Cartwright losing her mother in a tragic car accident. She does not get the chance to say goodbye to her mother due to the suddenness of the car crash. Max's mother was Amanda Cartwright, an actress who had starred an infamous 80s Slasher film called Camp Bloodbath playing a character called Nancy (most likely a tribute to A Nightmare on Elmstreet's Final Girl). In the original plot of the movie, Nancy does not survive, as she engages in sexual activity with another counselor and gets killed during the sex scene. 
Sometime after the car accident, Max's friends convince her to attend a tribute screening of her mother's film, in which they happen to be sucked into the movie and must survive the killer`s attacks. Camp Bloodbath focuses on camp counselors who are stalked and killed by the film's machete-wielding, masked killer. Nancy, Amanda Cartwright's character, is one of those counselors, and she joins Max and her friends in their attempt to escape/fight the killer.

However, Max and her friends have an advantage over the Camp Bloodbath characters, that is to say, the fact that they know they are inside a Slasher film, hence they know the rules to survive, one of them being not to engage in sexual activities. Knowing those rules is what allows them to change the script: therefore, Max stops Nancy from engaging in sexual activities with another counselor, so she remains a virgin and has a chance to survive, because they also know that one of the Slasher's conventions is that the Final Girl must be a virgin (even though Amanda Cartwright is Max's mother in the reality within the movie, in Camp Bloodbath, her character Nancy is still a virgin, and that is supposed to be enough to make her a possible Final Girl). Therefore, while both Max and Nancy are virgins, they also know there can be only one Final Girl, which is what makes Nancy surrender to allow Max to survive, as they both become close friends, since Max sees in Nancy her dead mother.

After Nancy surrenders to the killer, it is Max alone who must face him, as she faces her trauma of losing her mother so unexpectedly. According to Caruth, "trauma seems to be much more than a pathology, or the simple illness of a wounded psyche: it is always the story of a wound that cries out, that addresses us in the attempt to tell us of a reality or truth that is not otherwise available" (CARUTH, 1996, p. 4). So, in order to come to terms with her trauma, Max goes through the movie plot her mother starred on: she faces the story of her wound as it reopens every time she sees Nancy -- which is to her perhaps just as painful as the killer's attacks. By defeating the killer after Nancy willfully surrenders, Max finally puts an end to this constant return to her traumatic past, coming to terms with the tragic event that ended her mother's life once she is then able to say goodbye. By defeating the killer, she at once revenges her mother's death - letting out her anger 
both for the death of Amanda Cartwright in real life as well as for the murder of her character, Nancy, inside the movie. She relives her trauma by losing her mother again, and yet that gives her the chance to go through this event in a different circumstance, one in which she is more prepared and able to fight back, doing what she may believe would make her mother proud, that is, surviving. Thus, the movie shows the use of fiction as a way to come to terms with one's inner conflicts. Reliving trauma through fiction and experiencing this fiction within her own reality was how Max dealt with her trauma. Horror fiction can often be used that way:

Freud argues in Beyond the Pleaure Principle that children create games around the very things they most fear, as a way of subduing those fears and gaining control. Horror films are a safe, routinized way of playing with death, like going on the roller coaster or parachute jump at an amusement park (DICKENSTEIN 1980, p. 69, apud. STAIGER, 2016, p. 224).

Turning death and other dangers into movies, into stories and play, is a way of gaining control over them, which happens in most horror fictional works. Hence, we can say that the monsters in fiction are, in the end, reflections of our own inner monsters and, in order to get rid of them, or at least to learn how to tame them, we must bring them out of the dark where they can hold power over us. Once we turn them into narratives, we can understand better what they are and that is when they lose their power and become a story we can tell: and the good thing about stories is that they can always be changed, edited, rewritten, reinterpreted. That is why Nancy is able to fight Freddy Kruger, because she brings him out into the real world, makes him visible, vulnerable. By understanding what gave the monster life, she is able to defeat him and face her trauma at last. A similar situation happens to Max: only when she can understand the logic of the situation, she is able to control it, and only when she is given a chance to relive her trauma, she is able to come to terms with her grief. That is the power that fiction gives us, especially the power of horror stories: they help us fight our own monsters. Once we understand them, we can cope with them. 


\section{REFERENCES}

BACHELARD, Gaston. The Poetics of Space. Boston: Beacon Press Books, 1994.

CARROLL, Noël. The Philosophy of Horror. New York: Routledge, 1990.

CARUTH, Cathy. The Wound and the Voice. In: Unclaimed Experience: Trauma, Narrative, and History. Maryland: The Johns Hopkins University Press, 1996.

CLOVER, Carol J. Men, Women and Chain Saws: Gender in the modern horror film. New Jersey: Princeton University Press, 1992.

COHEN, J. J. Monster Theory. Minneapolis: University of Minnesota Press, 1996.

DIKA, Vera. Games of Terror: a definition, classification, and analysis of a subclass of the contemporary horror film, the stalker film (1978-1981). New York: New York University, 1985.

FRANÇA, Júlio. O sequestro do Gótico no Brasil. In: As Nuances do Gótico: do Setecentos à atualidade . Ed. FRANÇA, Júlio; COLLUCI, Luciana. Rio de Janeiro: Bonecker Editora, 2017, p. 111-124.

FREUD, Sigmund. Beyond the Pleasure Principle. New York: Liveright Publishing Corporation, 1961.

FREUD, Sigmund. The Ego and the Id. New York: Clydesdale Press, 2019.

FREUD, Sigmund. The Interpretation of Dreams. Hertfortshire: Wordsworth Editions, 1997.

FREUD, Sigmund.The Uncanny. Translated and edited by David McLintock. London: Penguin Classics, 2003.

HALBERSTAM, Judith. Bodies that Splatter: Queers and Chain Saws. In: Skin Shows: Gothic Horror and the Technoogy of Monsters. London: Duke University Press, 1995.

KING, Stephen. New York, Danse Macabre. New York: Simon and Schuster, 2011.

STAIGER, Janet. The Slasher, the Final Girl and the Anti-Denouement. In: Style and Form in the Hollywood film, Ed. Wickham Clayton. Houndsmill: Palgrave Macmillan, 2016, p. 213-281.

ZANINI, Claudio Vescia. "It hurts 'cause you're in my world now, bitch": Gothic features in the 1984 and 2010 versios of A Nightmare on Elm Street. In: Ilha 
do Desterro. Florianópolis, Volume 72, nº 1, 2019, p. 199-211.

ZANINI, Claudio Vescia. O Perverso e o Gótico em Jogos Mortais. In: Revista Abusões. Rio de Janeiro, Volume 1, no 1, 2015.

FILMS:

A Nightmare on Elm Street. Directed by Samuel Bayer, Platinum Dunes, 2010. Final Girls. Directed by Todd-Strauss-Schulson, Vertical Entertainment, 2015. 